\title{
The Implementation of Indeks Desa Zakat (IDZ) for Priority Areas of the Zakat Community Development (ZCD) Program for the Empowerment of Productive Mustahiq in South Kalimantan
}

\author{
Sri Maulida, Rizali, and Akhsanul Rahmatullah \\ Lambung Mangkurat University
}

\begin{abstract}
A number of different parties, from both the governmental and private sectors, have attempted various means of overcoming poverty, such as through a zakat institution. As an official zakat institution, BAZNAS has established the Zakat Community Development (ZCD) program. The ZCD program seeks to empower communities by targeting the mustahiq living in underdeveloped villages in terms of prosperity, facilities, and infrastructure. The program has the objective of enabling the members of mustahiq communities to help each other manage the funds provided by BAZNAS, so that their prosperity can be increased. Related to this program, BAZNAS has developed a measurement tool called the Indeks Desa Zakat, or IDZ, which emphasizes Islamic elements, such as those relating to religion, as its very important aspects, in addition to the economic, social, health, and education aspects. This research aims to answer questions regarding the overall condition of villages targeted for the ZCD program by central BAZNAS, in addition to identifying underdeveloped villages to prioritize for assistance. The results demonstrate that from the implementation of Indeks Desa Zakat (IDZ) calculations in the priority areas of the ZCD program, it can be concluded that among the three research locations, RT 34 Beruntung Jaya Village is the village that should be most highly prioritized for a ZCD program, with an index value of 0.48 . This value places the village in the good category based on the IDZ score range; therefore, it can be considered for assistance.
\end{abstract}

Keywords: Implementation, Indeks Desa Zakat, Zakat Community Development

\section{INTRODUCTION}

One of the fundamental issues facing every developing country is that of poverty. Countries such as Bangladesh, Cambodia, India, and Indonesia are developing countries, with the governments of each country always seeking to establish a range of programs aimed at reducing poverty. According to March 2018 data from the Central Statistics Agency, around 25.95 million people in Indonesia, or 9.82 percent of the population, live below the poverty line. Specifically, according to the head of BPS Kalsel, Diah Utami, the number of poor people in South Kalimantan (South Kalimantan) for the period September 2017-March 2018 had risen to 2,490 . This data reflects a rise in the number of poor people in urban society; in contrast, however, there has been a decline in the number of poor people in rural areas (http://banjarmasin.tribunnews.com/2018/0 8/01/data-bps- level -kemiskin-kalselterendah- di- kalimantan). 
Various parties, from both the governmental and private sectors, have made many attempts to tackle poverty and have launched a series of programs aimed at overcoming it. Through its use of the social scope of Islam, zakat development has been empirically proven to contribute to poverty reduction. According to Beik (2009), zakat can be empowered to realize public prosperity since it is one of the largest Islamic social instruments for handling poverty. Also, the role and functions of zakat administrators have started to be fixed and perfected along with such development, which also includes an organization for zakat administration in Indonesia by the name of Badan Zakat Nasional (BAZNAS). This administrator institution has the role of working to alleviate poverty, which in this context refers not solely to a narrow perspective but also incorporates a broader one. In general, zakat management has not previously included a wide perspective on poverty as it has been limited only to overcoming the problem of basic needs. Moreover, there has been no encouragement of community independence or community selfhelp (www.pusatbaznas.go.id).

The capability approach through community development is considered to be the best approach for zakat institutions to adopt. This approach prioritizes the empowerment process and establishes the community members as the owners of the program. The external role played by BAZNAS is thus solely to support the empowerment process. As an official zakat institution, BAZNAS has established the Zakat Community Development (ZCD) program. The ZCD program aims to empower the community by targeting mustahiq communities who live in underdeveloped villages in terms of their levels of prosperity, facilities, and infrastructure. The goal of the program is for members of the mustahiq community to help each other in managing the funds provided by BAZNAS, so that the prosperity of the mustahiq community can be increased.

These types of programs are conducted throughout Indonesia, including BAZNAS in South Kalimantan. In accordance with its principles, the ZCD program is implemented with the aim of assisting the mustahiq or beneficiaries within a specified geographical area or place based on various special conditions. $Z C D$ is a national program of BAZNAS that works in collaboration with Provincial BAZNAS, Regency or City BAZNAS, and other partners. Related to this program, BAZNAS has developed a measurement tool that places a special emphasis on Islamic elements, such as those relating to religion, as the very important aspects, alongside the economic, social, health, and education aspects. This tool is called the Indeks Desa Zakat, or IDZ, and can be used to measure or assess the condition of a village with the aim of categorizing it as either eligible or ineligible for funding by zakat.

In 2013, the BAZNAS ZCD program was carried out in 100 villages across Indonesia, three of which are in South Kalimantan Province - Ulin Village Simpur District in Hulu Sungai Selatan District; RT 34 Beruntung Jaya Village, Sungai Tiung Village, Cempaka District in Banjarbaru City; and Ujung Batu Village, Pelaihari District, Tanah Laut District. At the beginning of March 2018, BAZNAS in South Kalimantan Province launched a ZCD program in the village of Palimbangan Sari, Haur Gading Subdistrict, with assistance from BAZNAS of Hulu Sungai Utara Regency and BAZNAS of South Kalimantan Province (http://kalsel.baznas.go.id/berita/ BAZNAS -kalal-title-training-assessmentprogram-Zakat-community-developmentzcd.html). 
Based on this background, the researchers in this study are interested in conducting an assessment of the three villages deemed by central BAZNAS as being potentially eligible for assistance from the ZCD program. According to one of the Three Pillars of Higher Education comprising Education, Research and Community Service at the Faculty of Economics, Lambung Mangkurat University, this research will be useful to the community in South Kalimantan Province. Moreover, it relates to implementation of the ZCD by using the IDZ approach in order to empower productive mustahiq.

The research aims to answer questions regarding the overall condition of the villages targeted by central BAZNAS for the ZCD program, along with identifying other underdeveloped villages to prioritize for assistance. The results of this study can be used by BAZNAS in South Kalimantan province, BAZNAS Tanah Laut, BAZNAS Kandangan, and BAZNAS Banjarbaru City as a reference for the implementation of the ZCD program.

\section{LITERATURE REVIEW}

\section{Previous Research}

A number of previous studies have been conducted in Indonesia in the areas of the IDZ, ZCD, productive-based zakat, the religiosity of mustahiq, and the index calculation of certain villages. Herdayanti (2018), in her research entitled "The Measurement of $I D Z$ in Supporting the Zakat Community Development (ZCD) Program at Popongan Village, Semarang Regency," explained how the prosperity of the village was rated as good, with an index value of 0.56 . An index value in the range of $0.41-$ 0.60 indicates that, in general, the village in question is in good condition. Thus, according to its index value, Popongan Village is not prioritized; however, it might still be considered for assistance in the form of a ZCD program. This is due to the fact that the index value for the Economic dimension was 0.33 , meaning it does not have a particularly good economic condition and could thus be prioritized for assistance from zakat funding. The index value of the Health dimension was 0.60 , while an index value of 0.55 was recorded for the Social and Humanity dimension. It can thus be concluded that although the health and social and humanity conditions of the community are good enough, it could still be considered for assistance. Moreover, the Education and Da'wah dimensions had index values of 0.72 and 0.68 , respectively. Generally, the Education and Da'wah dimensions of the community are good, which means that the village is not prioritized for assistance from the perspective of either of these dimensions. Based on the data, it can be seen that the lowest index value was for the Economic dimension, at 0.33 , with the highest for the Education dimension, at 0.72 .

Aside from an index calculation based on the religious aspect, the calculation of index values can also be based on the classification of villages, such as in the Indeks Desa Membangun (IDM). The IDM was developed by the Ministry of Villages in 2015. Setyobakti (2017), in his research, looked at the condition of a village based on the IDM. The results served to illustrate both the deficiency and potency in Gondowangi Village. The village was examined using the variables and indicators of the IDM. In the field, it was found that Gondowangi Village falls within the category of sub-urban village, so that the nature of society is united, not geographically separated. Gondowangi Village is close to the community service center, including a service center that was built by the village authority. There are basic service facilities and infrastructure 
available in the village; however, there is suboptimal utilization of these services, which is why the community needs to optimize them. The supporting potential in this village comprises the availability of human resources, a proactive village authority, local culture such as garbage management, and an economic institution in the form of Bumdesa.

Sartika (2008), who carried out research at LAZ Surakarta Solo Care Foundation, explains the impact of productive zakat on the income of mustahiq. A similar study was conducted by Beik (2009), who used tools of analysis such as the headcount ratio (to determine the total and percentage of poor families), poverty gap ratio, and income gap ratio (used to ascertain the poverty level of the community), in addition to the Sen index and the Foster-Greerdan-Thorbecke (FGT) indices (used to measure the seriousness of poverty). The results of the study indicated that a productive zakat fund is capable of significantly increasing the income of mustahiq. In addition, the poverty analysis revealed that zakat can reduce the percentage of poor families and the severity of poverty.

Rusli et al. (2015) set out to analyze the impact of productive zakat in the form of financial capital for business, as awarded to the poor community by the Baitul Mall of North Aceh District. This financial capital was given in an effort to ameliorate the poverty situation in North Aceh District. The results of this research demonstrated the positive impacts of awarding productive zakat in the form of financial capital for business, with it being shown to have reduced the level of poverty in North Aceh District by $0.02 \%$; however, the authors also pointed to the fact that this type of effort can be improved.

Mafruhah et al. (2015) also conducted research related to the ZCD program, entitled "The Implementation of Zakat Community Development (ZCD) concept in Empowerment of productive mustahiq in Sukoharjo District." Their study was a collaboration between the researchers and society based on the zakat function of continuous strategic efforts in helping people who lack ability in both economic and business terms to become more capable and independent. The results of the study showed that (1) dissemination by Baitul Maal is able to increase understanding with regard to communitybased zakat, and (2) community-based fundraising efforts can yield positive results in terms of improving the performance of Zakat Collecting Unit (Unit Pengelola Zakat or abbreviated as UPZ) and public access in the utilization of zakat.

\section{Zakat}

The term zakat is derived from the basic word zaka, which means holy, blessed, growing, and praiseworthy. In terms of Fiqh, zakat denotes a certain quantity of assets that Allah instructs should be handed over to those who have a right to receive them (Qardhawi, 1997: 34). Allah SWT mentions zakat and prayer in a total of 82 verses, thus making zakat the most important pillar of Islam after prayer.

The foundation of zakat as an obligation is mentioned in Qur'an Surat Al-Baqaraah, verse 43: "Establish prayer and give zakat and bow with those who bow (in worship and obedience)." From the hadits narrated on the authority of Abdullah bin Umar, Rasulullah SAW said: "Islam is built on five pillars: testifying (the fact) that there is no God except Allah, Muhammad SAW is the messenger of Allah, and establishment of prayer, paying of zakat, pilgrimage to the House (Ka'ba) and the fast of Ramadhan" (HR Bukhari and Muslim). There is also an Ijma Ulama (agreement of ulama) in relation to both ulama salaf (classical) and khalaf (contemporary), with an agreement on the obligation of zakat. They state that a denial by anyone of this 
obligation equates to their disbelief in the principles of Islam.

Muzakki or zakat payers are people who are obliged to pay zakat from their property. According to Jumhur Ulama, a zakat payer is required to be a Muslim but is not required to be baligh or intelligent. Mustahiq, meanwhile, are those people who are entitled to receive zakat. Allah SWT states the following in Surah AtTaubah verse 60: "The alms are meant only for the poor and for the needy and for those employed to collect (zakat) and for those whose hearts are to be reconciled and for freeing captives (or slaves) and for those in debt and for expenditure in the Way of Allah and for the wayfarer. This is an obligation from Allah, and Allah is AllKnowing and All-Wise."

\section{The National Board of Zakat}

The National Board of Zakat, or BAZNAS, is the official and only institution established by the government based on the Republic of Indonesia Presidential Decree No. 8 of 2001. Its function as an institution is the collection and distribution of zakat, infaq, and alms at the national level. Law Number 23 of 2011, which relates to zakat management, accords BAZNAS the capacity, as an authorized institution, to handle the national management of zakat.

In terms of the law, BAZNAS is deemed to be a non-structural government institution that is independent yet accountable to the President through the Minister of Religion. Therefore, BAZNAS works together with the government and is responsible for overseeing the management of zakat based on Islamic law, a mandate, expediency, justice, legal certainty, integration, and accountability. BAZNAS performs the following four functions: planning for the collection, distribution, and utilization of zakat; implementation of the collection, distribution, and utilization of zakat; control of the collection, distribution, and utilization of zakat; and reporting of and accountability for the implementation of zakat management.

In order to perform these duties and functions, BAZNAS has the authority to collect, distribute, and utilize zakat; to provide recommendations concerning the formation of BAZNAS at the Province, Regency/City, and LAZ levels; and to request reports from BAZNAS at the Province and LAZ levels on the implementation of zakat management, donation, charity, religious, and other social funds.

\section{Zakat Community Development (ZCD) Program}

The ZCD program is a community development program aimed at integrating social aspects (education, health, religion, environment, and other social aspects) and comprehensive economic aspects. It is mainly funded by zakat, infaq, and alms, with the objective of realizing a prosperous and independent community. The ZCD program covers community development activities in various aspects of life, with that result that the community will be empowered in the four areas of education, health, economy, and religious life, collectively termed "Caturdaya Masyarakat”. Caturdaya Masyarakat forms the main element of a ZCD program, with each of the areas being interrelated. As a result, a community that has fulfilled these four elements of Caturdaya Masyarakat can be categorized as prosperous and independent.

The ZCD program incorporates six principles that must be listed in the concept and stages of a program's implementation. The zakat administrators also have to understand these principles. The six principles of ZCD are: community-based, Islamic Sharia, participation, utilization, sustainability, and synergy. The overall objective of a 
ZCD program is the realization of a prosperous and independent community. In addition, however, there are the following specific objectives: fostering mustahiq/beneficiaries' awareness of the quality of life; boosting participation in community independence; growing a network of socioeconomic societies, and creating a sustainable empowerment program for realizing a prosperous and independent community.

\section{Indeks Desa Zakat (IDZ)}

The Indeks Desa Zakat, or IDZ, created by the Research Team and Pusat Kajian Strategis (Puskas) of BAZNAS, is a tool used to measure and/or assess the condition of a village, with the aim of determining whether or not it is eligible to receive funding in the form of zakat. According to Puskas of BAZNAS, IDZ can also be used as a monitoring and evaluation tool for the zakat management process in a village. The $I D Z$ is based on the process-oriented principle, which enables it to be used by zakat institutions. This index is used to monitor the progress of a BAZNAS program.

The IDZ consists of five dimensions, namely Economic, Health, Education, Social and Humanity, and Da'wah. Each dimension comprises 15 variables and 39 indicators, which are assigned contribution weightings. The constituent parts of the IDZ are given in Table 1:

Table 1. Components of the Indeks Desa Zakat (IDZ)

\begin{tabular}{|c|c|c|c|c|c|}
\hline Dimension & $\begin{array}{l}\text { Weighted } \\
\text { Score }\end{array}$ & Variable & $\begin{array}{l}\text { Weighted } \\
\text { Score }\end{array}$ & Indicator & $\begin{array}{l}\text { Weighted } \\
\text { Score }\end{array}$ \\
\hline \multirow[t]{6}{*}{$\begin{array}{l}\text { Economic } \\
\left(\mathrm{X}_{1}\right)\end{array}$} & 0.25 & $\begin{array}{c}\text { Productive } \\
\text { economic } \\
\text { activities }\left(X_{11}\right)\end{array}$ & 0.28 & $\begin{array}{c}\text { Superior product } \\
\text { diversification / } \\
\text { production center } \\
\text { (defined) }\left(\mathrm{X}_{111}\right)\end{array}$ & 0.33 \\
\hline & & & & $\begin{array}{l}\text { Participation level of } \\
\text { the workforce }\left(\mathrm{X}_{112}\right)\end{array}$ & 0.35 \\
\hline & & & & $\begin{array}{l}\text { There is a creative } \\
\text { industry } \\
\text { community }\left(\mathrm{X}_{113}\right)\end{array}$ & 0.32 \\
\hline & & $\begin{array}{l}\text { Village trade } \\
\text { center }\left(\mathrm{X}_{12}\right)\end{array}$ & 0.24 & $\begin{array}{l}\text { There is a market as a } \\
\text { trading facility and a } \\
\text { provider of } \\
\text { community needs, } \\
\text { both traditional and } \\
\text { online marketing } \\
\left(\mathrm{X}_{121}\right)\end{array}$ & 0.53 \\
\hline & & & & $\begin{array}{l}\text { There is a trading } \\
\text { place (shopping sites, } \\
\text { minimarkets, food } \\
\text { stalls, culinary center) } \\
\left(\mathrm{X}_{122}\right)\end{array}$ & 0.47 \\
\hline & & $\begin{array}{l}\text { Transportation } \\
\text { access and } \\
\text { logistics /shipping } \\
\text { services }\left(\mathrm{X}_{13}\right)\end{array}$ & 0.22 & $\begin{array}{c}\text { Accessibility of } \\
\text { village roads }\left(\mathrm{X}_{131}\right)\end{array}$ & 0.42 \\
\hline
\end{tabular}




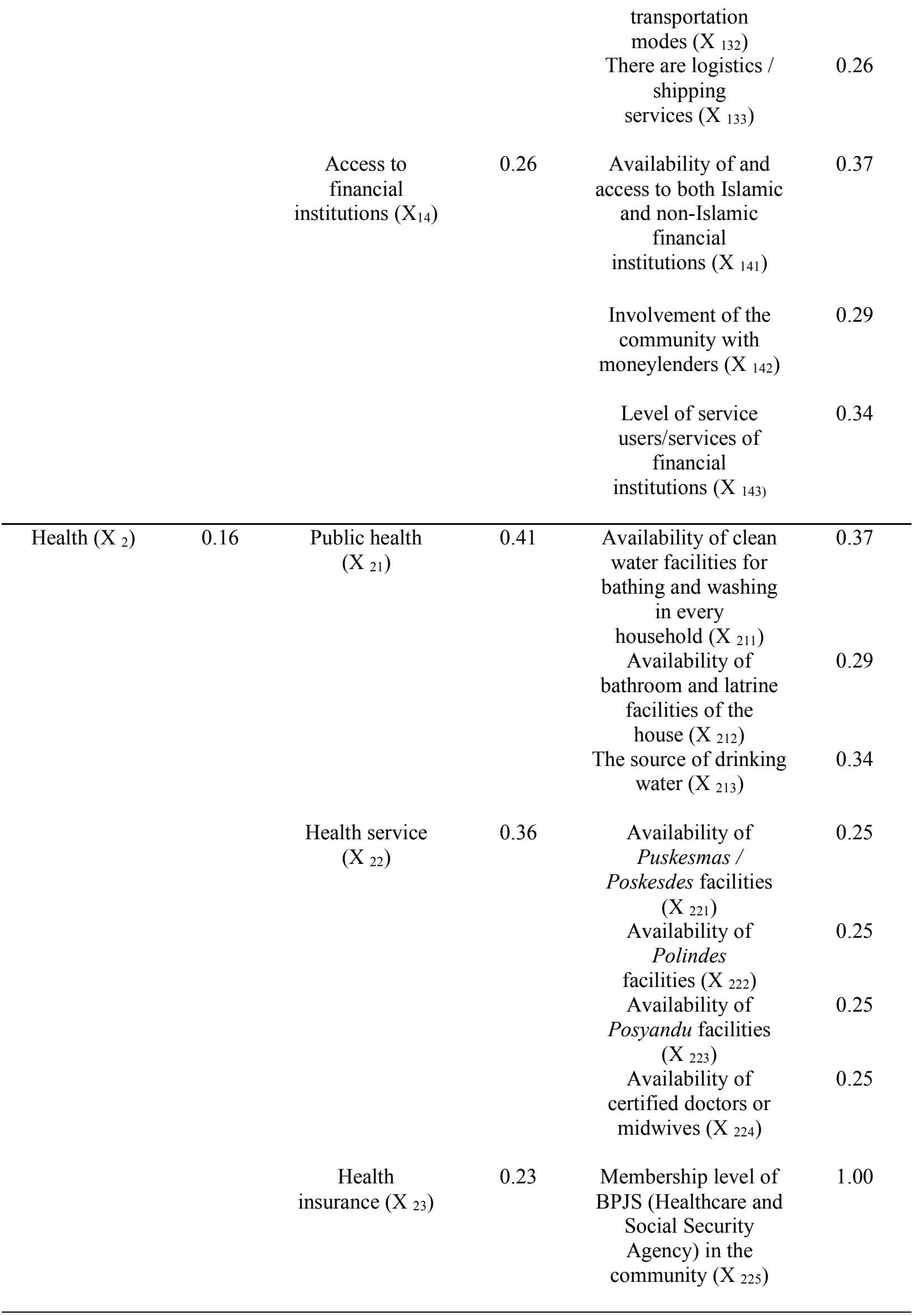




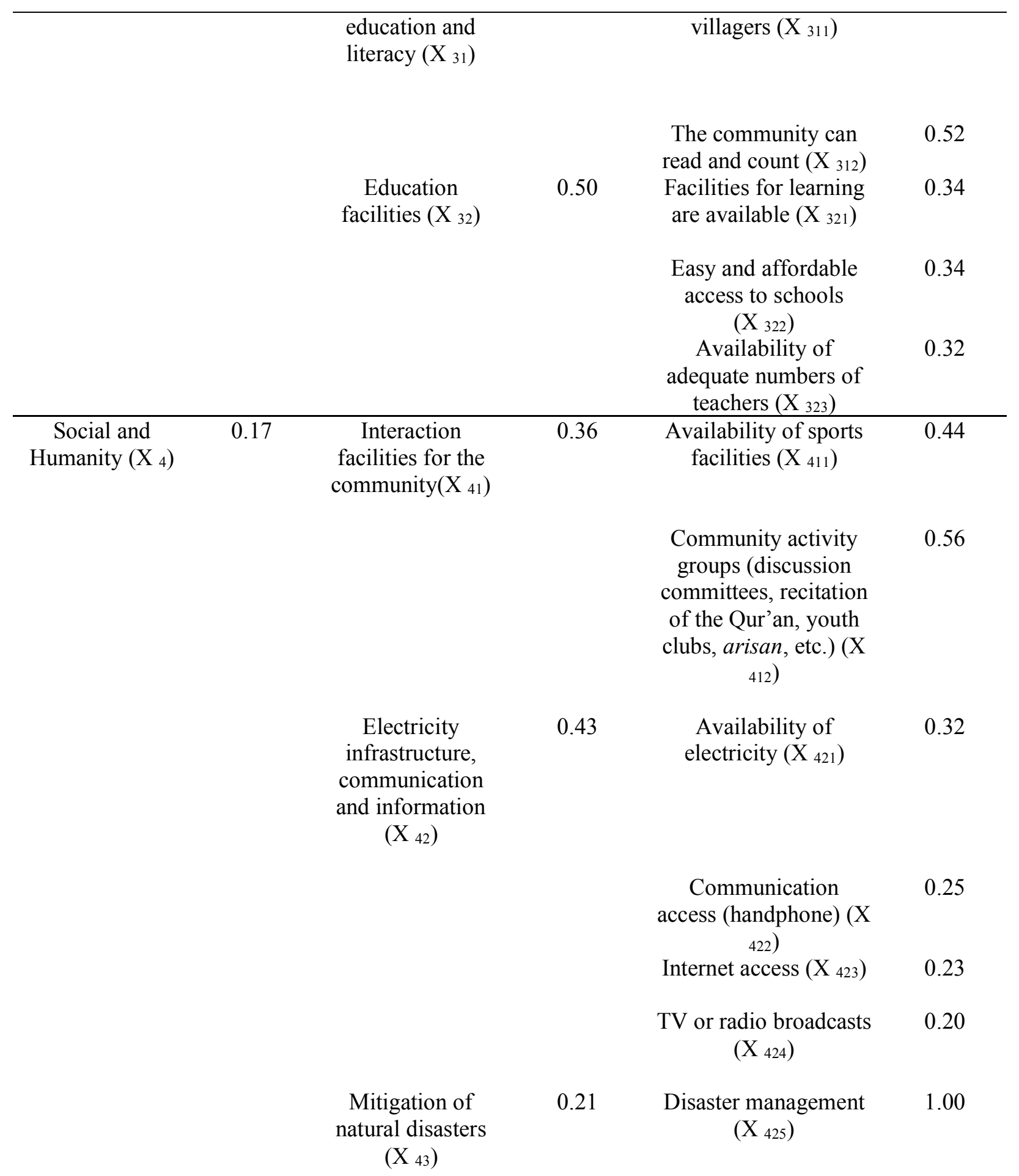

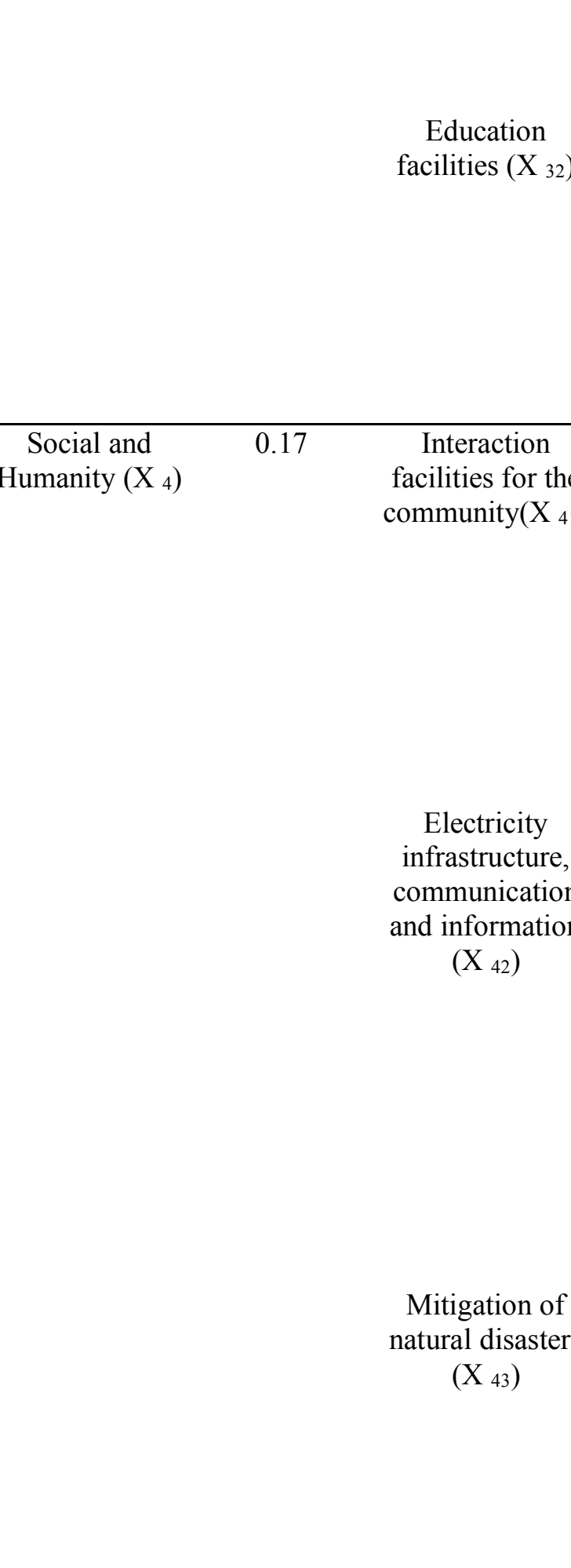

$\begin{array}{lll}\text { Da'wah }\left(\mathrm{X}_{5}\right) & 0.22 \quad \text { Availability of }\end{array}$ religious facilities

0.33 $\left(\mathrm{X}_{51}\right)$

Availability of a mosque in the neighborhood $\left(\mathrm{X}_{511}\right)$

Mosque access ( $\left.\mathrm{X}_{512}\right)$ 
Level of religious knowledge of the community $\left(\mathrm{X}_{52}\right)$

Level of community participation in religious activity $\left(\mathrm{X}_{53}\right)$
Presence of religious associates (religious teachers, etc.) (X 513)

$$
\begin{gathered}
\text { Al-Qur'an literacy } \\
\text { level of } \\
\text { community }\left(\mathrm{X}_{521}\right) \\
\text { Public awareness of } \\
\text { zakat } \text { and infaq } \\
\text { (sharing with fellow } \\
\text { human beings) ( } \left.\mathrm{X}_{522}\right) \\
\text { Implementation of } \\
\text { routine religious } \\
\text { activities ( } \left.\mathrm{X}_{531}\right)
\end{gathered}
$$

Level of community participation in 5times-daily prayer in the way of jama'ah (X 532 )

Level of community participation in routine religious activities (weekly or monthly Qur'an recitation) $\left(\mathrm{X}_{533}\right)$
An index score will be calculated in respect of each of these dimensions, which will eventually produce a final score in the form of the $I D Z$.

\section{METHODOLOGY}

\section{The Types of Data and Data Sources}

This research is categorized as field research. In this type of research, data are sourced directly from the research objects (i.e., social community) in a certain region. There are two forms of data source in this research, namely secondary data and primary data. The secondary data were obtained from various sources, including that published by the central and regional arms of BAZNAS. The primary data were obtained through the conducting of interviews with village heads or the heads of neighborhood associations. In this respect, the villages are prioritized for a ZCD program by BAZNAS in South Kalimantan using a checklist in the form of a Likert scale, based on the collection of documentation and secondary data from various sources.

\section{The Research Schedule and Location}

This research was conducted during the period August-September 2018. The data collection was carried out by interviewing the informants from the research locations, namely in RT 34 Beruntung Jaya Village (Sungai Tiung Village, Cempaka District in Banjarbaru City), Simpur Village (Hulu Sungai Selatan District), and Ujung 
Batu Village (Pelaihari District in Tanah Laut City).

\section{The Analysis Method}

The analysis method used in this research is the Indeks Desa Zakat or IDZ (Pusat Kajian Strategis BAZNAS, 2017). The methods employed to calculate, score, and evaluate the procedures of IDZ are as follows:

First, each indicator is assessed using a five-point Likert scale, with the value of 1 being the lowest and 5 being the highest. As such, a village scoring higher values on this scale is not prioritized for assistance, while a village with low scores will be considered to be prioritized for assistance.

Second, after obtaining the actual figures (based on adjustment of the facts, findings, and data obtained from the Likert scale criteria), the indicator is calculated using the following method:

Indicator $_{x}=\frac{\left(\text { score }_{x}-\text { Score }_{\text {min }}\right)}{\left(\text { score }_{\max }-\text { Score }_{\min }\right)}$

where:

Indicator ${ }_{x}$ : the value of $x$ Indicator

Score $_{x}$ : the score on $\mathrm{x}$ Indicator

Min score : 1 (the smallest value)

Max score : 5 (the biggest value)

Once the value for an indicator has been obtained, it is then multiplied by the respective weight of each indicator in order to obtain an indicator index. The indicator indices are grouped according to the variable and multiplied by the weight of each variable to obtain the variable index.

Third, the index of each variable is multiplied by the weight in each dimension to obtain the dimension index. The result is a composite index that can be referred to as IDZ. The formula is as follows:
$I D Z=(X 1 e k+X 2 k s+X 3 p e+X 4 k e+X 5 d a)(\mathrm{ii})$

Where:

IDZ: Indeks Desa Zakat /Zakat Village Index

X1 .... X5: Weight of assessment

ek: Economic dimension

ks: Health dimension

pe: Education dimension

ke: Social and humanity dimension

da: Da'wah dimension

To derive the IDZ weight, the following formula is used to calculate the indicator, variable, and dimensional weights:

$I D Z_{=} 0.25 X_{1}+0.16 X_{2}+0.20 X_{3}+0.17 X_{4}+$ $0.22 x_{5}$

Where:

$\mathrm{X}_{1}$ : Economic

$\mathrm{X}_{2}$ : Health

$\mathrm{X}_{3}$ : Education

$\mathrm{X}_{4}$ : Social and Humanity

$\mathrm{X}_{5}:$ Da'wah

Economic Dimension

$$
\begin{gathered}
X_{1=} 0.28 X_{11}+0.24 X_{12}+0.22 X_{13}+ \\
0.26 X_{14} \\
X_{11=}=0.33 X_{111}+0.35 X_{112}+ \\
0.32 X_{113} \\
\\
X_{12=}=0.53 X_{121}+0.47 X_{122} \\
X_{13}=0.42 X_{131}+0.32 X_{132}+ \\
0.26 X_{133} \quad(\mathrm{vii}) \\
X_{14}=0.37 X_{141}+0.29 X_{142}+ \\
0.34 X_{143}
\end{gathered}
$$

where:

$\mathrm{X}_{1}$ : Economic dimension

$\mathrm{X}_{11}$ : Productive economic activities

$\mathrm{X}_{12}$ : Village trade center

$\mathrm{X}_{13}$ : Transportation access and logistics /shipping services

$\mathrm{X}_{14}$ : Access to financial institutions

$\mathrm{X}_{111}$ : Superior product diversification / production center (defined)

$\mathrm{X}_{112}$ : Participation level of workforce 
$\mathrm{X}_{113}$ : There is a creative industry community

$\mathrm{X}_{121}$ : There is a market as a trading facility and a provider of community needs, both traditional and online marketing

$\mathrm{X}_{122}$ : There is a trading place (shopping sites, minimarkets, food stalls, culinary center)

$\mathrm{X}_{131}$ : Accessibility of village roads

$\mathrm{X}_{132}$ : There are public transportation modes

$\mathrm{X}_{133}$ : There are logistics / shipping services

$\mathrm{X}_{141}$ : Availability of and access to both Islamic and non-Islamic financial institutions

$\mathrm{X}_{142}$ : Involvement of the community with moneylenders

$\mathrm{X}_{143}$ : Level of service users/services of financial institutions

$$
\begin{aligned}
& \text { Health Dimension } \\
& X_{2=}=0.41 X_{21}+0.36 X_{22}+0.23 X_{23} \text { (ix) } \\
& X_{21}=0.37 X_{211}+0.29 X_{212}+ \\
& 0.34 X_{213} \\
& X_{22}=0.25 X_{221}+0.25 X_{222}+ \\
& 0.25 X_{223}+0.25 X_{224} \\
& X_{23}=1
\end{aligned}
$$

where:

$\mathrm{X}_{2}$ : Health dimension

$\mathrm{X}_{21}$ : Public health

$\mathrm{X}_{22}$ : Health services

$\mathrm{X}_{23}$ : Health insurance

$\mathrm{X}_{211}$ : Availability of clean water facilities for bathing and washing in every household

$\mathrm{X}_{212}$ : Availability of bathroom and latrine facilities of the house

$\mathrm{X}_{213}$ : The source of drinking water

$\mathrm{X}_{221}$ : Availability of Puskesmas / Poskesdes facilities

$\mathrm{X}_{222}$ : Availability of Polindes facilities $\mathrm{X}_{223}$ : Availability of Posyandu facilities
$\mathrm{X}_{224}$ : Availability of certified doctors or midwives

$$
\begin{aligned}
& \text { Education Dimension } \\
& X_{3}=0.50 X_{31}+0.50 X_{32} \\
& X_{31}=0.48 X_{311}+ \\
& 0.52 X_{312} \\
& X_{32}=0.34 X_{321}+0.34 X_{322}+ \\
& 0.32 X_{323}
\end{aligned}
$$

where:

$\mathrm{X}_{3}$ : Education dimension

$\mathrm{X}_{31}$ : Level of education and literacy

$\mathrm{X}_{32}$ : Education facilities

$\mathrm{X}_{311}$ : Education level of villagers

$\mathrm{X}_{312}$ : The community can read and count

$\mathrm{X}_{321}$ : Facilities for learning

$\mathrm{X}_{322}$ : Easy and affordable access to schools

$\mathrm{X}_{323}$ : Availability of adequate numbers of teachers

$$
\begin{array}{cc}
\multicolumn{3}{c}{\text { Social and Humanity Dimension }} \\
X_{4=} 0.36 X_{41}+0.43 X_{42}+0.21 X_{43} \quad \text { (xvi) } \\
X_{41=}=.44 X_{411}+0.56 X_{412} \quad \text { (xvii) } \\
X_{42=0.32 X_{421}+0.25 X_{422}+} \\
0.23 X_{423}+0.20 X_{424} \quad \text { (xviii) } \\
X_{43=1} \quad \text { (xix) }
\end{array}
$$

where:

$\mathrm{X}_{4}$ : Social and Humanity dimension

$\mathrm{X}_{41}$ : Interaction facilities for the community

$\mathrm{X}_{42}$ : Electricity infrastructure, communication and information

$\mathrm{X}_{43}$ : Mitigation of natural disasters

$\mathrm{X}_{411}$ : Availability of sports facilities

$\mathrm{X}_{412}$ : Community activity groups (discussion committees, recitation of the Qur'an, youth clubs, arisan, etc.)

$\mathrm{X}_{421}$ : Availability of electricity

$\mathrm{X}_{422}$ : Communication access (handphone)

$\mathrm{X}_{423}$ : Internet access

$\mathrm{X}_{424}$ : TV or radio broadcasts 
Da'wah Dimension

$$
\begin{aligned}
X_{5=} & 0.33 X_{51}+0.30 X_{52}+0.37 X_{53} \quad(\mathrm{xx}) \\
& X_{51=}=0.31 X_{511}+0.32 X_{512}+ \\
& 0.37 X_{513}(\mathrm{xxi}) \\
& X_{52}=0.46 X_{521}+0.54 X_{522} \quad(\mathrm{xxii}) \\
& X_{53}=0.30 X_{531}+0.39 X_{532}+ \\
& 0.31 X_{533} \quad(\mathrm{xxiii})
\end{aligned}
$$

where:

$\mathrm{X}_{5}:$ Da'wah dimension

$\mathrm{X}_{51}$ : Availability of religious facilities

$\mathrm{X}_{52}$ : Level of religious knowledge of the community

$\mathrm{X}_{53}$ : Level of religious activity and community participation

$\mathrm{X}_{511}$ : Availability of a mosque in the neighborhood

$\mathrm{X}_{512}$ : Mosque access

$\mathrm{X}_{513}$ : Presence of religious associates (religious teachers, etc.)
$\mathrm{X}_{521}$ : Al-Qur'an literacy level of community

$\mathrm{X}_{522}$ : Public awareness of zakat and infaq (sharing with fellow human beings)

$\mathrm{X}_{531}$ : Implementation of routine religious activities

$\mathrm{X}_{532}$ : Level of community participation in 5-times-daily prayer in the way of jama'ah

$\mathrm{X}_{533}$ : Level of community participation in routine religious activities (weekly or monthly Qur'an recitation)

The IDZ values range between 0 and 1. The results of the IDZ will be divided into five categories or score ranges, as described in the following table.

Table 2. IDZ Score Ranges

\begin{tabular}{ccc}
\hline Score range & Information & Interpretation \\
\hline $0.00-0.20$ & Not good & Highly prioritized for assistance \\
$0.21-0.40$ & Not good & Prioritized for assistance \\
$0.41-0.60$ & Pretty good & Can be considered for assistance \\
$0.61-0.80$ & Good & Less prioritized for assistance \\
$0.81-1.00$ & Very good & Not prioritized for assistance \\
\hline
\end{tabular}

Source: Puskas BAZNAS 2017

Table 2 thus shows that as its IDZ value approaches 1 , a village is less prioritized. In contrast, an IDZ value closer to 0 indicates that the village will be prioritized for assistance.

\section{RESULT AND DISCUSSION}

Based on the measurements of IDZ, RT 34 Beruntung Jaya Village is the most highly prioritized village for assistance from a ZCD program. This result is based on measurements for the five dimensions of the score index, namely the Economic, Health, Education, Social and Humanity, and Da'wah dimensions. More detailed results for each research location are presented in the following tables.

Table 3. IDZ for Ulin Village

\begin{tabular}{cccc}
\hline No. & Dimension & Weight & Index \\
\hline 1 & Economic $\left(\mathrm{X}_{1}\right)$ & 0.25 & 0.35 \\
2 & Health $\left(\mathrm{X}_{2}\right)$ & 0.16 & 0.73 \\
3 & Education $\left(\mathrm{X}_{3}\right)$ & 0.20 & 0.60 \\
4 & Social and Humanity $\left(\mathrm{X}_{4}\right)$ & 0.17 & 0.64
\end{tabular}




$5 \quad$ Da'wah $\left(\mathrm{X}_{5}\right)$
$\mathrm{IDZ}$ Scores for Ulin Village

The greatest weighting in the IDZ calculation is for the Economic dimension. However, the results shown in Table 3 reveal that the lowest score among the five dimensions for Ulin Village is also for the Economic dimension, at 0.35 . The lowest research weighting is for the Health dimension, although the finding from the field was that the health index has the second highest value, of 0.73 , after the Da'wah dimension value of 0.89 . This is followed by the Education and Social and Humanity dimensions with their variable index values of 0.64 and 0.60 , respectively.

For the Economic dimension, there are no productive economic activities in Ulin Village producing creative products such as those that are typically produced by creative industries. Most of the villagers work as farmers, and there is only one village trade center in Ulin Village in the form of a traditional market, which operates every Thursday. The transportation access is very limited, and there are no logistics/shipping services.

In respect of the Health dimension, it can be said that the villagers are very healthy because this village has health services. Also, members of the community are registered for health insurance, which is organized by the government. The village scores well against the Education and Social and Humanity dimensions. Indeed, there are many facilities provided that are needed in order for teaching and learning activities to take place. Interaction facilities for the community are also provided in the form of a tennis table. However, there is no mitigation of natural disasters in Ulin Village. From the other dimensions, Da'wah has the highest index value, which reflects the fact that there is a mosque and 11 langgar in the village. There is also majelis taklim (Islamic Forum) managed by an ustazd (spiritual teacher). Sometimes, the ustazd, as the organizer of majelis taklim, invites the habaib or 'ulama to a twice-weekly AlQur'an recitation event.

Table 4. IDZ Ujung Batu Village

\begin{tabular}{cccc}
\hline No. & Dimension & Weight & Variable Index \\
\hline 1 & Economic $\left(\mathrm{X}_{1}\right)$ & 0.25 & 0.38 \\
2 & Health $\left(\mathrm{X}_{2}\right)$ & 0.16 & 0.80 \\
3 & Education $\left(\mathrm{X}_{3}\right)$ & 0.20 & 0.73 \\
4 & Social and Humanity $\left(\mathrm{X}_{4}\right)$ & 0.17 & 0.70 \\
5 & Da'wah $\left(\mathrm{X}_{5}\right)$ & 0.22 & 0.86 \\
$\mathrm{IDZ}$ Scores for Ujung Batu Village & \\
$\mathrm{IDZ}=0,25 X_{1}+0,16 X_{2}+0,20 X_{3}+0,17 X_{4}+0,22 x_{5}$ \\
$\mathrm{IDZ}=0,25(0,38)+0,16(0,80)+0,20(0,73)+0,17(0,70)+0,22(0,86)$ \\
$\mathrm{IDZ}=0,10+0,13+0,15+0,12+0,19$ \\
IDZ $=0,68 \quad$ \\
Source: Primary data $(2018)$
\end{tabular}


The condition of Ujung Batu Village is similar to that of Ulin Village. Table 4 indicates that the lowest index value for Ujung Batu Village is also for the Economic dimension, with a score of 0.38. The Da'wah and Health Dimensions occupy the first and second positions, respectively, with weights of 0.86 and 0.80 . These are followed by the Education dimension with an index of 0.73 , and, finally, the Social and Humanity dimension, which has the lowest index score of 0.70 .

The economic sector in Ujung Batu is considered to be the best among other villages. This is because this village has a range of agricultural, plantation, and livestock products such as rice, palm oil, tomatoes, chillies, goats, cows, chickens, and other livestock. However, Ujung Batu Village has very little in the way of creative productive economic activities, with traditional gold mining being the only form. All of the villagers are permitted to mine gold using traditional tools due to the availability of a small mining area that belongs to the public. Every Saturday, there is a village market where the community can engage in the purchase and sale of goods. For transportation services, despite there being no fixed-route public transportation, people are able to travel outside the area using a number of transportation services. People can call transport agencies who will pick up passengers from their homes. On the financial literacy side, there are three groups of merchants led by women entrepreneurs in Ujung Batu Village. These groups are financed by one of the Islamic banks in Indonesia to enable them to conduct their business, thus meaning they do not have to borrow from moneylenders.

The village scores well in both the Health and Education dimensions, reflecting the many health and education facilities available. Ujung Batu Village has one soccer field for sports, which has a border with the market and junior high school. The village also has a Fire Department located in the Village Office. The index for the Da'wah dimension in Ujung Batu Village is very high due to the fact that its religious facilities are well regulated by the village administration. In 2017, the regency administration conducted a Safari Ramadhan event at AlKhif Mosque in Ujung Batu Village, donating 100 million rupiahs to the mosque. Moreover, the mosque received 10 prayer rugs from various banks in South Kalimantan, and 10 copies of Al-Qur'an from the religious community. As a result of this assistance, the village is making progress with regard to religious literacy, facilities, and infastructure.

Table 5. IDZ for RT 34 Beruntung Jaya Village

\begin{tabular}{cccc}
\hline No. & Dimension & Weight & Index \\
\hline 1 & Economic $\left(\mathrm{X}_{1}\right)$ & 0.25 & 0.28 \\
2 & Health $\left(\mathrm{X}_{2}\right)$ & 0.16 & 0.80 \\
3 & Education $\left(\mathrm{X}_{3}\right)$ & 0.20 & 0.38 \\
4 & Social and Humanity $\left(\mathrm{X}_{4}\right)$ & 0.17 & 0.35 \\
5 & Da'wah $\left(\mathrm{X}_{5}\right)$ & 0.22 & 0.57 \\
IDZ Scores for RT 34 Beruntung Jaya Village & \\
IDZ $=0,25 X_{1}+0,16 X_{2}+0,20 X_{3}+0,17 X_{4}+0,22 x_{5}$ \\
IDZ $=0,25(0,28)+0,16(0,80)+0,20(0,38)+0,17(0,35)+0,22(0,57)$ \\
IDZ $=0,07+0,13+0,08+0,06+0,13$ \\
IDZ $=0,46$
\end{tabular}

Source: Primary data (2018) 
RT 34 Beruntung Jaya Village has the lowest ratings across all of the dimensions examined. The village is difficult to find due to a lack of road signs. It is also categorized as a neighborhood association, with the number of households reaching 100 families. Table 5 reveals that the Economic dimension has the lowest index value of 0.28 , with the highest index value of 0.80 for the Health dimension. In third position is the Da'wah dimension with an index value of 0.57 , followed by the Education dimension on 0.38 and, finally, the Social and Humanity dimension on 0.35 .

The majority of the community in this village is made up of farmers, who earn an income through agricultural activity and selling seasonal fruits such as durian. There is no productive economic activity in the village, and there is no trade center. Logistics/shipping services can be carried out only within the district due to the difficulty of transportation access, and there is a very low level of public literacy on finance. RT 34 Beruntung Jaya Village scores better on the Health dimension, however, with there being health care and health professionals in the village to treat people's health issues. Health insurance is also provided for the villagers, coordinated by the district and the village administrators. RT 34 Beruntung Jaya Village has a relatively low score on the Education dimension, with a majority of the villagers completing only an elementary school level of education. This helps to explain the low level of literacy among people in the village. RT 34 Beruntung Jaya Village has no sports facilities, good Internet access, or natural disaster mitigation. Religious activity is only carried out once a week, at night. This leads to a situation where only a few villagers join religious activity because they prefer to rest at night. A summary of the analysis of the IDZ results for each research location is given as follows:

Table 6. IDZ Values in the ZCD Village Program

\begin{tabular}{cccccccc}
\hline No. & Village & \multicolumn{5}{c}{ Dimension Score Index } & IDZ \\
\cline { 3 - 6 } & & Economic & Health & Education & $\begin{array}{l}\text { Social and } \\
\text { Humanity }\end{array}$ & Da'wah & \\
\hline 1 & Ulin & 0.09 & 0.12 & 0.12 & 0.11 & 0.20 & $\mathbf{0 . 6 3}$ \\
2 & Ujung Batu & 0.10 & 0.13 & 0.15 & 0.12 & 0.19 & $\mathbf{0 . 6 8}$ \\
3 & RT 34 & 0.07 & 0.13 & 0.08 & 0.06 & 0.13 & $\mathbf{0 . 4 6}$ \\
& Beruntung & & & & & & \\
\hline \multicolumn{3}{c}{ Jaya Village } & & & & &
\end{tabular}

Source: Primary data (2018)

Based on the IDZ scores displayed in Table 6, Ulin and Ujung Batu Villages fall within the good category, which means they are less prioritized for assistance. It can be seen that the scores range between 0.61 and 0.80 . RT 34 Beruntung Jaya Village, meanwhile, falls within the category of good enough, thus indicating that it can be considered for assistance. RT 34 Beruntung Jaya Village has scores in the range $0.41-0.60$, which therefore makes it the most highly prioritized for assistance from a ZCD program. RT 34 Beruntung Jaya Village has the lowest IDZ score, followed by Ulin and Ujung Batu villages. The latter two have scores approaching 1, which means they are not prioritized for assistance.

According to the analysis, RT 34 Beruntung Jaya Village can be considered as being eligible for assistance in the form of a ZCD program, which seeks to develop communities by integrating a range of social aspects (education, health, religion, environment, and other social aspects) and overall economic aspects, with funding from zakat, infaq, and alms funds. The overall goal of this type of program is 
the creation of a prosperous and independent community.

\section{CONCLUSION AND RECOMMENDATION}

Based on the results of the research and discussion presented in the previous chapter, and from implementing the IDZ calculations in the priority areas of the ZCD program, it can be concluded that out of the three research locations, RT 34 Beruntung Jaya Village is the village that is accorded the highest priority for a ZCD program, with an index value of 0.48 . This value is categorized as good enough, and, according to the IDZ score range, means that it can be considered for assistance.

This research can form a reference for BAZNAS in South Kalimantan with regard to the implementation of a ZCD program in RT 34 Beruntung Jaya Village. This village contains cattle and goat farms, in addition to a beautiful forest that may be used for nature-based halal tourism. There could also be increased development of quality farming in Ulin Village, and it is also highly recommended that creative industries for women are developed in Ujung Batu.

\section{REFERENCES}

BAZNAS Kalsel (2017). Dapat diakses pada website http://kalsel.baznas.go.id/berita/bazn as-kalsel-gelar-pelatihan-assessmentprogram-zakat-communitydevelopment-zcd.html

Beik, I., S. (2009). Analisis peran zakat dalam mengurani Kemiskinan: Studi Kasus Dompet Dhuafa Republika. Jurnal Pemikiran dan Gagasan Vol II.

Herdayanti, N. (2018). Pengukuran Indeks Desa Zakat Dalam Mendukung Program Zakat Community Development (Studi Kasus: Desa
Popongan Kabupaten Semarang). Departemen Ilmu Ekonomi Syariah Fakultas Ekonomi Dan Manajemen Institut Pertanian Bogor.

Mafruhah, I., Ismoyowati, D., Istiqomah, N., \& Sri Mulyani, N. (2015). Implementasi konsep Zakat Community Development (ZCD) dalam rangka pemberdayaan mustahiq produktif di Kabupaten Sukoharjo. Jurnal Sustainable Competitive Advantage (SCA), 5(1): Proceeding Seminar Nasional \& Call for Papers (SCA 5).

Pusat Kajian Strategis Baznas (2017). Indeks Desa Zakat: Dari Desa untuk Zakat yang Terukur dan Berkemajuan. Jakarta Pusat: Puskas BAZNAS.

Putera, A. D. (2018). BPS: Maret 2018, Persentase Kemiskinan Indonesia Terendah Sejak 1999, dapat diakses pada website https://ekonomi.kompas.com/read/20 18/07/16/130732026/bps-maret2018-persentase-kemiskinanindonesia-terendah-sejak-1999.

Qardhawi, Y. (1997). Fiqhu Al-Zakat Dirasah Muqaranah Li Alkamiha Wa Falsafatiha Fi Dau'al-Qur'an Wa Al-Sunnah (Beirut: Muassasah al-Risalah). Cet XXIV

Rusli, A. H., \& Syahnur, S. (2013). Analisis dampak pemberian modal zakat produktif terhadap pengentasan kemiskinan dikabupatenaceh utara. Jurnal Ilmu Ekonomi Pascasarjana Universitas Syiah Kuala, 1(1), 5663.

Sartika, M. (2008). Pengaruh pendayagunaan zakat produktif terhadap pemberdayaan mustahiq pada LAZ Yayasan Solo Peduli Surakarta. Jurnal Ekonomi Islam LaRiba, II(1), 75-89.

Setyobakti, M. H. (2017). Identifikasi masalah dan potensi desa berbasis Indek Desa Membangun (IDM) di desa gondowangi kecamatan wagir Kabupaten Malang. Jurnal 
Penelitian Ilmu Ekonomi WIGA, 7, $1-14$.

Sugiyono (2012). Metode Penelitian Kunatitatif Kualitatif dan $R \& D$. Bandung. Alfabeta.
Sri Maulida

Lambung Mangkurat University Indonesia

srimaulida@ulm.ac.id

Rizali

Lambung Mangkurat University Indonesia

hrizali1107@gmail.com

Akhsanul Rahmatullah Lambung Mangkurat University Indonesia akhsanalkhalis@gmail.com 